\title{
Bibliography of selected primary sources
}

\section{MANUSCRIPTS}

BODLEIAN LIBRARY, OXFORD

Ashmole MSS

Bankes MSS

Rawlinson MS A.I69 Papers on Marshalsea Court

Rawlinson MS D.8 I 8 Miscellaneous papers relating to see of London

\section{BRITISH LIBRARY}

Lansdowne MSS

5/30 Instructions for erecting a house of correction in Westminster, c. 1563

$7 / 21$ Orders for Westminster in the time of plague, 1563

I0/26 Contributors to the building of a market house in St Margaret, Westminster, I 568

I 4/36 Provision for the poor in St Martin's, St Clement Danes, Savoy and Westminster, I 572

I6/74 Account of collections for the poor in Westminster, I 573

21/30 Petition of shoemakers of Westminster, I 575

26/66 Shoemakers of Westminster to Lord Burghley, I 578

35/32 Account of inmates within Westminster, I 582

43/74 Observations on parliamentary bill concerning Westminster, I 585

44/48 Names of headboroughs and boundaries of their wards in Westminster (wrongly identified in catalogue as London), c. 1585

\section{Harleian MSS}

832 Collection of papers relating to the creation of St Paul Covent Garden

I83 I Register book made by the burgesses and assistants of Westminster, c. I 660

Cotton MSS

Julius C, III Letter of Dean Williams of Westminster to Sir Robert Cotton, I 628

Trumbull MSS

\section{CAMBRIDGE UNIVERSITY LIBRARY}

Dd.I4.25 Diary of John Somers

CHATSWORTH HOUSE, DERBYSHIRE

Bolton MSS Accounts of the earls of Cumberland 


\section{DURHAM CATHEDRAL ARCHIVES}

Hunter MS 44 Memorials of the almanac books of William Neile, I 593-I624

\section{GUILDHALL LIBRARY，LONDON}

MS 953I/I 2, I3, I 5 Registers of Bishop of London

MS 9537/I 4, I 5 Visitation Call Books, I636-37

MS I 520I/2 Vintners' Company Court Minutes

\section{HAMPSHIRE RECORD OFFICE}

MS 44M69/F6 Diary of Sir Richard Paulet, I6IO

\section{HATFIELD HOUSE, HERTFORDSHIRE}

Correspondence, household cash books and miscellaneous bills

Accts I60/5 Household accounts of the second earl of Salisbury, I 62 I-25

\section{HOUSE OF LORDS RECORD OFFICE}

Draft bill 27 Eliz. I c. 47

Main Papers I625, I640, I64I, I642

\section{LAMBETH PALACE LIBRARY}

MS658 Richard Webster to the earl of Essex, I 596

Shrewsbury MS 709 Petition of Westminster inhabitants for the suspension of the 1585 Act Carte Misc. 7/79/5 Return of St Martin's vestry, I635/6

$\mathrm{COMM} \mathrm{XIIa/I2}$ Interregnum valuations of clerical stipends

\section{LONDON METROPOLITAN ARCHIVES}

Consistory Court of London

$\mathrm{DL} / \mathrm{C} / 300$ Office Act Book, Jul. I 583-Mar. I 583/84

DL/C/306 Office Act Book, Nov. I607-June I609

DL/C/308 Office Act Book, May I609-Oct. I6I I

DL/C/3IO Office Act Book, Nov. I6II-Oct. I6I3

DL/C/3I2 Office Act Book, Nov. I6I2-Oct. I6I5

DL/C/3I3 Office Act Book, Nov. I6I5-Mar. I6I6/I7

$\mathrm{DL} / \mathrm{C} / 3 \mathrm{I} 5$ Office Act Book, Nov. I6I9-May I62I

$\mathrm{DL} / \mathrm{C} / 3 \mathrm{I} 6$ Office Act Book, Oct. I620-June I624

DL/C/6I7 Vicar General's Book I6I6-23

Middlesex Sessions

MJ/SBR Sessions of the peace registers, I608-67

WJ/SR (NS) I-5 Westminster sessions of the peace rolls, I620-I 844 


\section{Bibliography}

THE NATIONAL ARCHIVES, LONDON (FORMERly pUblic

RECORD OFFICE)

C2 Chancery Proceedings

C3 Chancery Proceedings

$\mathrm{C}_{5}$ Chancery Proceedings

C66 Chancery, Patent Rolls

Ci I 5 Chancery, Masters' Exhibits

Ci 8 I Chancery, Crown Office, Entry Books of Commissioners

E36 Exchequer, Treasury of the Receipt, Miscellaneous Books

Eı I Exchequer, King's Remembrancer, Miscellanea

Eı 24 Exchequer, King's Remembrancer, Entry Books of Orders

Eı35 Exchequer, Miscellaneous Ecclesiastical Documents

Eı63 Exchequer, King's Remembrancer, Miscellanea of the Exchequer

EI78 Exchequer, King's Remembrancer, Special Commissions of Inquiry

EI79 Exchequer, King's Remembrancer, Lay Subsidies (assessments, certificates, etc.)

E2 I 5 Exchequer, King's Remembrancer, Commissions on Fees

E35I Exchequer, Various Accounts

PC2/4I-52 Privy Council Registers (June I63I-September I640)

PCC/Prob. I I Prerogative Court of Canterbury, Will Registers

REQ2 Court of Requests, Proceedings

$\mathrm{SO}_{3}$ Signet Office Docquet Books

SPI 2 State Papers Domestic, Elizabeth I

SPr4 State Papers Domestic, James I

SPr6 State Papers Domestic, Charles I

STAC 5 Star Chamber Proceedings, Elizabeth I

STAC8 Star Chamber Proceedings, James I

\section{SHEFFIEL CITY ARCHIVES}

Strafford Papers, Wentworth Woodhouse Muniments, vols 6, I 2 Elmhirst Pye Papers MS I287(c)

SIDNEY SUSSEX COLLEGE, CAMBRIDGE

Muniments Box I9/I I Will of the Countess of Sussex

\section{SURREY HISTORY CENTRE}

MS LM/I989 Loseley MSS, Petition concerning disputed parliamentary election in Westminster, I 62 I

MS LM/I33I/27 Further petition concerning the I62I election

\section{WESTMINSTER ABBEY MUNIMENTS}

Accounts, Fraternity of the Virgin's Assumption (I I I 5-2I) and St Mary Rounceval (I 520-24, $1538-40$ ) bound in a single volume with earlier guild accounts

Chapter Act Book, vol. II, I609-42 
Muniment Book 7 (the Dean's Book)

Muniment Book I 5

Register books II, VI, XIII

WAM 5299A Account of the 'bounds' of the 'Cittie of Westminster and the liberties thereof, temp. James I

WAM 6557 Precis of contents of proposed incorporation of Westminster, I607

WAM 6558 Details of New Incorporation

WAM 6559 Dean and chapter's objections to proposed New Incorporation of the Suburbs, I630s

WAM 6560 Further objections of dean and chapter to New Incorporation, I630s

WAM 656I Copy of proposed incorporation of Westminster, I633, with comments of Dean Williams, and copy of WAM 6587

WAM 6562 Petition for separate Westminster sessions, pre-I6I 8

WAM 6586 Draft charter of incorporation for Westminster, I607

WAM 6587 Collated objections of dean and chapter to draft charter of incorporation

WAM 9340 Order and rules for house lately built for the poor of St Margaret's, temp. Elizabeth I

WAM 9353 List of poor inhabitants in the ward of Maurice Pickering, I 595

WAM 9628 Bond of William Jeve, as bailiff of Westminster, I6I 8

WAM 9629 Indenture of 1620 parliamentary election in Westminster

WAM 963 I Draft letter from the dean and chapter making void the appointment of James Lowman as bailiff and escheator, 1622

WAM 9886 Letters patent for the appointment of the earl of Buckingham as high steward, I6I 8

WAM I72I2 Inquisition into the Lammas grounds in St Martin in the Fields held in common with St Margaret Westminster, I 592

WAM 25029 View of poor and impotent in St Margaret's, I 578

WAM 25095 Dean Williams's defence against charges, I630s

WAM 25109 Memorandum of royal commission for visitation of Westminster college, January I 637

WAM 37252 Easter book, St Margaret Westminster, I 549

WAM 37494-37547 List of those receiving alms from Abbey, mid-Tudor

WAM $3755^{\circ}$ Easter book, St Margaret Westminster, I 554

WAM 38I26 Renunciation of churchwardens of St Margaret Westminster and appointment of successors, I 562

WAM 57269 Petition from vicar of St Martin in the Fields concerning a church rate, I608

\section{WESTMINSTER ARCHIVES CENTRE}

St Clement Danes

Parish registers, I (I $55^{8-1644)}$

BI Accounts, Surveyors of the highways I $58 \mathrm{I}-\mathrm{I} 62 \mathrm{I}$

B9 Accounts of church building expenses 1575

BI9 Accounts, overseers for the poor I604-II

B2I Accounts, overseers for the poor I6I7-18

St Margaret Westminster

E2-6 Churchwardens' accounts I 510-I6IO

E8 Churchwardens' accounts $1612-13$

EI3-2I Churchwardens' accounts I 622-40

E22 Relief of poor visited with plague, I638-39

E23 Churchwardens' accounts I640-42

EI44 Accounts, collectors for the poor, I 56I-62, I 565-7 I

EI 45-I48 Accounts, collectors for the poor, I 572-99 


\section{Bibliography}

EI49-I 5I Accounts, overseers for the poor, I600-24

EI 52-I 54 Accounts, overseers for the poor, I624-40, including 'special account' for relief of plague victims, I 625

E24I3 Vestry minutes, I 59I/2-I66I/2

St Martin in the Fields

F2 Churchwardens' accounts I604-24

$\mathrm{F}_{3}$ Churchwardens' accounts I 624-47

F30I Accounts, collectors for the poor, I 574-75

F304-3I I Accounts, collectors for the poor, I 577-84

F3I 2-3I7 Accounts, collectors for the poor, I 585-9I

F319-324 Accounts, collectors for the poor, I 592-98

F 325-352 Accounts, overseers for the poor, I 598-I626

F353-360 Accounts, overseers for the poor, I626-34

F36I-368 Accounts, overseers for the poor, I635-42

F200I Vestry minutes I 574-1623

F2002 Vestry minutes I624-52

F3354 Rate for the visited poor, collector's book, Landside, I625

F3355 Rate for the poor visited, I630

F3356 Names and assessments of those out of town (incomplete), I636

F45II-45I 2 Accounts, Examiners for visited houses, I 625

F45I4 Subscription for relief of plague sufferers, list of premises shut by plague, I 636-38

F45 I 5 Churchwardens' disbursements for poor visited, I63 I

F45 I6 Accounts, collectors for poor visited, I636-37

F6036 Certificate of churchwardens and vestry to Thomas, earl of Suffolk, concerning a lecturer recommended by him, I6I 5

F6039 Survey of the poor, $1602 / 3$

PCW Peculiar Court of Westminster, wills, registers and act books, I 504-I 858

WCB I Minutes, Westminster Court of Burgesses I6IO-I3

WCB2 Minutes, Westminster Court of Burgesses I6I3-I6

I656/I Minute Book of the Court of Governors, St Margaret's Hospital, I64I-I737

\section{YORK MINSTER ARCHIVE}

Add I8 Archbishop Matthew's preaching diary

\section{Printed PRIMARY SOURCES}

Place of publication is London, unless otherwise stated.

The Account Books of St Bartholomew Exchange, ed. E. Freshfield (I 895)

Acts of the Dean and Chapter of Westminster, I543-1609, ed. C.S. Knighton (Westminster Abbey Record Series, I-II, I997-99)

Acts of the Privy Council of England, ed. J.R. Dasent (32 vols., I 890-1907)

Hugh Alleys' Caveat: The Markets of London in 1598, ed. I. Archer, C. Barron and V. Harding (London Topographical Society, I37, I988)

Anon., Two Sermons [funeral sermon of Thomas Montfort] (I632) 
The Arraignment of John Selman (16I2)

Bargrave, Isaac, A Sermon against Selfe Policy (1624)

- A Sermon preached before the Honourable Assembly (1624)

Barrington Family Letters I628-32, ed. A. Searle (Camden Society, 4th ser., 28, 1983)

Cabala (1654)

Calendar of the Correspondence of the Smyth Family of Ashton Court 1548-1642, ed. J.H. Bettey (Bristol Record Society 35, I982)

Calendar of the Patent Rolls, Edward VI, Philip and Mary, Elizabeth (I924-86)

Calendar of State Papers, Domestic

Calendar of State Papers, Venetian

Calendar of Wynn of Gwydir Papers 1515-1690 (Aberystwyth, I926)

Records of the Worshipful Company of Carpenters, ed. B. Marsh, J. Ainsworth and A.M. Millard (7 vols., I9I4-68)

A Catalogue of Westminster Records, ed. J.E. Smith (1900)

Wyllyam Cecill knight, high steward of the citie of Westminster . . to the Baylyffe (I 564)

The Letters of John Chamberlain, ed. N.E. McClure (2 vols., Philadelphia, 1939)

The Diaries of Lady Anne Clifford, ed. D.J.H. Clifford (Stroud, I990)

Commons Debates in I62I, ed. W. Notestein, F. Relf and H. Simpson (7 vols., New Haven, I935)

Commons Debates for I629, ed. W. Notestein and F.H. Relf (Minneapolis, I92I)

The Works of John Cosin, ed. J. Sansom (5 vols., Oxford, I843-55)

Private Correspondence of Lady Jane Cornwallis, ed. Lord Braybrooke (I842)

The Court and Times of Charles I, ed. R.F. Williams (2 vols., I 848)

Cyvile and Uncyvile Life: a discourse where is disputed, what order of Lyfe best beseemeth a Gentleman

( 579 ) - another issue reprinted in W.C. Hazlitt (ed.), Inedited Tracts (I 868)

Dekker, Thomas, The Dead Terme. Or Westminsters Complaint for Long Vacations (I608)

The Diary of Sir Simonds D'Ewes, ed. E. Bourcier (Paris, 1974)

The Journal of Sir Simonds D'Ewes from the Beginning of the Long Parliament, ed. W. Notestein (New Haven, I923)

A Deep Sigh Breath'd through the lodgings at Whitehall (1642)

Two Diaries of the Long Parliament, ed. M. Jansson (New York, 1984)

A Discourse of the Common Weal, ed. E. Lamond (Cambridge, I893)

Documentary Annals of the Reformation, ed. E. Cardwell (2 vols., Oxford, I844)

The Complete English Poems of John Donne, ed. C.A. Patrides (1985, reprt, I990)

Egerton Papers, ed. J. Payne Collier (Camden Society I2, I840)

Everard, John, The Arriereban (I 6I 8)

- Some Gospel Treasures Unopened (1653)

Featley, Daniel, Clavis Mystica (I636)

Ceremonies of Charles I: the Note Books of John Finet, I628-I64I, ed. A.J. Loomie (New York, I987) 


\section{Bibliography}

Fisher, William, A Sermon Preached at Paules Crosse (I 580 )

Forsett, Edward, A Defence of the Right of Kings (1624)

Foxe, John, Acts and Monuments, ed. S.R. Catley (8 vols., I 838 )

Fuller, Thomas, History of the Worthies of England (I 662)

Gataker, Thomas, Certaine Sermons (I637)

— A Discours Apologeticall (1654)

The workes of . . Richard Greenham (5th ed., 16I2)

Hacket, John, Scrinia reserata (I693)

The Autobiography of Lady Anne Halkett, ed. J.G. Nichols (Camden Society, n.s. I3, I875)

Harrison's Description of England, ed. F.J. Furnivall (4 parts, I877-I908)

Hill, Robert, The Contents of Scripture (I 596)

- Christs Prayer Expounded A Christian Directed A Communicant Prepared (I606)

- A Godly and Learned Exposition or the Commentarie upon the three first Chapters of the Revelation (I607)

The Pathway to Prayer and Pietie ( $\left.\mathrm{I}_{6} \mathrm{I}_{3}\right)$

Historical Manuscripts Commission:

- Cowper II

- De l'Isle and Dudley VI

- Downshire VI

— Hastings

— Hatfield House/Salisbury (24 vols., I883-1976)

- Seventh Report

The Diary of Lady Margaret Hoby, ed. D.M. Meads (1930)

Letters of John Holles 1587-1637, ed. P.R. Seddon (Thoroton Society, 31, 35-6, I975-86)

The Holles Account of Proceedings in the House of Commons, ed. C. Thompson (Orsett, I985)

Howes, Edmund, Annales (I63I)

Howell, James, Epistolae Ho-Elianae (5th ed., I678)

- Londinopolis ( 1657 )

The Political Works of James I, ed. C. McIlwain (Cambridge, Mass., I9I8)

James, Richard, Marmora Arundeliana (1628)

The Works of Ben Jonson, ed. C.H. Herford, P. Simpson and E.M.S. Simpson (I I vols., Oxford, I925-52)

Journals of the House of Commons

Journals of the House of Lords

The Journals of Two Travellers in Elizabethan and Early Stuart England, ed. P. Razzell (I995)

Household Accounts and Disbursement Books of Robert Dudley, Earl of Leicester, ed. S. Adams (Camden Society, 5th ser., 6, I995)

Letters and Memorials of State, ed. A. Collins (2 vols., I746) 
Letters and Papers, Foreign and Domestic, of the reign of Henry VIII, ed. J.S. Brewer, J. Gairdner and R.H. Brodie (I862-I932)

'William Latymer's Cronickille of Ane Bulleyne', ed. M. Dowling, Camden Miscellany XXX(Camden Society, 4th ser., I990)

Ley, Roger, Two Sermons (I619)

London and Middlesex Chantry Certificate, 1548 , ed. C.J. Kitching (London Record Society, I6, 1980)

The Diary of Henry Machyn, Citizen and Merchant-Taylor of London, 1550-1563, ed. J.G. Nichols (Camden Society 42, I848)

Memorials of St Margaret's Church Westminster: The Parish Registers, 1539-I600, ed. A.M. Burke (I9I4).

Middlesex County Records, ed. J.C. Jeaffreson (4 vols., I 886-92)

Calendar of Middlesex Sessions Records, ed. W. Le Hardy (4 vols., I935-4I)

Minutes of Parliament of the Middle Temple, ed. C.T. Martin (3 vols., I904)

Montford, Thomas, A Sermon Preached at the Funeral of Lady Blount (I6I9)

Moryson, Fynes, An Itinerary Containing His Ten Yeeres Travell (4 vols., I907-8)

Narratives of the Days of the Reformation, ed. J.G. Nichols (Camden Society, 77, I859)

'The undergraduate account book of John and Richard Newdigate, I6I8-2I', ed. V. Larminie, Camden Miscellany 30 (Camden Society, 4th ser., 39, 1990)

Norden, John, Speculum Britanniae, Description of Middlesex (I 593)

The Norwich Census of the Poor, I570, ed. J.F. Pound (Norfolk Record Society 40, I97I)

The Order of the Communion, 1548 , ed. H.A. Wilson (1908)

The Oxinden Letters I607 to I642, ed. D. Gardiner (1933)

The Parochial Charities of Westminster, First Report of the Trustees (Westminster, I890)

Peacham, Henry, Coach and Sedan (1636)

- The Art of Living in London ( I 642), ed. V. Heltzel (Cornell, N.Y., I962)

- The Gentlemens Exercise (1612)

A Petition of the Citie of Westminster (1643)

Thomas Platter's Travels in England in 1599, ed. C. Williams (I937)

Poor Relief in Elizabethan Ipswich, ed. J. Webb (Suffolk Records Society 9, I966)

Poverty in Early Stuart Salisbury, ed. P. Slack (Wiltshire Record Society 3I, Devizes, 1975)

The Private Journals of the Long Parliament 7 March to I June I642, ed. V.F. Snow and A.S. Young (New Haven, 1987)

Proceedings in the Parliaments of Elizabeth I, ed. T.E. Hartley (3 vols., Leicester, I98 I-95)

Proceedings in Parliament, I6IO, ed. E.R. Foster (2 vols., I966)

Proceedings in Parliament I626, ed. W. Bidwell and M. Jansson (4 vols., New Haven, I99I-96)

Queen Elizabeth and Her Times, ed. T. Wright (2 vols., I838)

Jacobean Recusant Rolls for Middlesex, ed. J.J. LaRocca (Catholic Record Society 76, I997)

A Register of Baptisms, Marriages, and Burials in the Parish of St. Martin-in-the-Fields . . from I550 to I6I9, ed. T Mason (Harleian Society Registers, 25, I898) 


\section{Bibliography}

The Register of St Martin-in-the-Fields I619-1636, ed. J.V. Kitto (Harleian Society Registers, 36, 1936)

A Transcript of the Registers of the Company of Stationers, 1554-1640, ed. E.A. Arber (5 vols., London and Birmingham, I875-94)

Les Reportes del Cases in Camera Stellata 1593-1609, ed. W. Baildon (I894)

Reports of Cases in the Courts of Star Chamber and High Commission, ed. S.R. Gardiner (Camden Society, n.s. 39, I886)

St Martin-in-the-Fields. The Accounts of the Churchwardens, I525-I603, ed. J.V. Kitto (I901)

The Seconde Parte of a Register, ed. A. Peel (2 vols., Cambridge, I9I 5 )

Sheldon, Richard, The First Sermon of R. Sheldon priest, after his Conversion (I6I2)

Shirley, James, The Lady of Pleasure, ed. R. Huebert (Manchester, 1986)

Stow, John, A Survey of London, ed. C.L. Kingsford (2 vols., Oxford, I908)

The Earle of Strafforde's Letters and Despatches, ed. W. Knowler (2 vols., 1739)

Strype, John, A Survey of the Cities of London and Westminster (2 vols., I720)

- Ecclesiastical Memorials (6 vols., I 822)

Memorials of Thomas Cranmer (2 vols., I 840)

Stuart Royal Proclamations, ed. J. Larkin and P. Hughes (2 vols., 1973-83)

Synodalia, ed. E. Cardwell (Oxford, I 842)

Taylor, John, The Brownists Synagogue (I64I)

The Book of Architecture of John Thorpe, ed. J. Summerson (Walpole Society 40, I966)

The London Surveys of Ralph Treswell, ed. J. Schofield (London Topographical Society, I35, 1987)

Tudor Royal Proclamations, ed. P.L. Hughes and J.F. Larkin (3 vols., New Haven, I964-69)

The Vestry Minute Book of the Parish of St Bartholomew Exchange in the City of London, 1567-1676, ed. E. Freshfield (I 890)

Visitation Articles and Injunctions of the Early Stuart Church, ed. K. Fincham (2 vols., Church of England Record Society I, 5, I994-98)

Visitation Articles and Injunctions of the Period of the Reformation, ed. W.H. Frere and W.P. Kennedy (3 vols., 1910)

The Diary of Baron Waldstein, ed. G.W. Groos (I98I)

Historical Notices . . by Nehemiah Wallington (2 vols., I 869)

Walsingham, Francis, A Search Made into Matters of Religion (St Omer, I609)

Waterhouse, Edward, The Gentleman's Monitor (1665)

Whitelocke, Bulstrode, Memorials of the English Affairs (1732)

The Diary of William Whiteway, ed. D. Underdown (Dorset Record Society I2, I99I)

Willet, Andrew, Sacrorum Emblematum Centuria Una (? I 592)

- Synopsis Papismi (1634)

Wren, Christopher, Parentalia (I750)

Wriothesley, C., A Chronicle of England During the Reigns of the Tudors, ed. W.D. Hamilton (2 vols., Camden Society, n.s., I I, 20, I875-77) 